\title{
THE ROLE OF FOLKLORE IN THE FORMATION OF LATVIAN VISUAL ART
}

\author{
Toms Kencis
}

\begin{abstract}
Latvian folklore, folk ornament, and mythology were an established symbolic capital upon which the second generation of ethnic Latvian artists built a national particularity of visual art during the fin de siècle decades. The construction of national art represents artistic and discursive processes of exchange and conflict between the imperial centre and the local periphery, the Baltic German elite and ethnic Latvian artists, international styles and local particularities. The idea of national art developed within the framework of free discussion, borrowing models of identity from more mature art scenes abroad as well as from other areas of cultural representation, like folklore and ethnography. As a result, several coexisting versions of national art identity are distinguished in the given period. Visual arts were 'nationalised' through form - developing particular ethnographic patterns of ornamentation - or through content, the latter ranging from local landscapes and people to motifs of ancient history, folklore, and mythology. Although developments in visual arts follow the international pattern, the application of conclusions emerging from a wider field of studies on cultural nationalism shows that folklore has played a special role due to the particular setting of cultural production in Latvia.
\end{abstract}

Keywords: art criticism, Finland, folklore, Latvia, mythology, nationalism, visual arts

\section{INTRODUCTION}

Artworks are declared to be a part of national heritage, particular artists are proclaimed to be national artists, and certain works are included in the national canon of art. These processes are retrospective and related to both the professional and the public perception of art history. However, before them lie discursive fields of present/past: the creation of artworks is always embedded in particular socio-political environments, discussed within critical stances, supported or hindered by institutional, academic, and bureaucratic apparatuses. Being a part of them, each artwork creates, challenges, and comments on the aesthetic dispositions of its time. Each artwork is a mute record of the artist's voice, related to his or her personality, part of his or her oeuvre. The 
long nineteenth century gave birth to modern nationalism and the first wave of nation-states that appeared on the stage of history. The second wave followed the collapse of empires after the Great War and the Russian revolution. The result was the emergence of multiple, relatively small, ethnocentric new states in Northern, Eastern and Central Europe, for example, Finland (1917), Poland, Hungary, Czechoslovakia, Estonia, and Latvia (1918), the latter being examined in detail below. The political act of declaring independence was preceded by decades of social change and the ideological formation of so-called national awakenings, partially taking shape also in the realm of cultural production or, as Miroslav Hroch (1985) has titled it, the phase of cultural nationalism. The case of Latvia at the turn of the century provides rich material for mapping various nationalising strategies of symbolic heritage making, the piratisation (cf. Anderson 2006 [1983]) of models of nationalism, the adaptation of international art styles and genres, and discursive practices manoeuvring between multiple identity models. While both the role of folklore in constructing Latvian national identity and recently also Latvian art history around the turn of the century have been studied quite extensively, the aim of this article is to bring together knowledge from both fields. Such an approach would allow us to capture the mechanics of transfer of certain imagery from popular to elite intellectual systems, establishing also a basis for studying the reflexive relationship between both systems.

\section{THE CONDITIONS OF ARTISTIC PRODUCTION}

Contemporary Latvia, once located at the western edge of the Russian Empire, was comprised of part of Die deutschen Ostseeprovinzen Russlands (the German Baltic Provinces of Russia), which were mainly protestant countries and held some of the industrially most advanced cities in the empire, and part of the Province (guberniya) of Vitebsk. It was a German cultural area with Baltic German and German-speaking elites, mainly populated by ethnic Latvians ${ }^{1}$ and ruled by Russian imperial laws within the geopolitical framework of the empire. For the emerging Latvian nationalism this situation provided a set of choices. The more conservative circles of the 1870s aligned with Baltic German proLatvian, relatively liberal Lettisch-Literärische Gesellschaft or Latviešu Draugu biedrība, ${ }^{2}$ while others proclaimed allegiance to Russian central governmental bodies, gaining a foothold against local Baltic-German elites. The turn of the century saw the introduction of the influential social-democratic revolutionary generation of $1905 .{ }^{3}$ The Latvian national movement was definitely not consolidated at the end of the century, nor was the vision of national culture. 
Despite historiographical efforts to background multinational connections in the studies into art history carried out during the period of national independence as well as under the Soviet occupation, the local art scene "was mainly determined by the coexistence of German and Latvian cultural powers, ranging from mutual forthcoming and stimulating rivalry to politicised confrontation" (Ābele 2006: 39). A more mundane but nevertheless influential factor was the art market: the most profitable was the genre of the representational portrait (Kḷaviňs 1996), and artists as well as critics regularly complained that local audiences were not inclined to invest in artworks at all (e.g. Ābele 2006: 42). Regardless of the artists' nationality, the majority of buyers purchasing local artworks were of Baltic German origins. However, the artworks were sold also in other regions of the empire and in Western Europe.

The circles of people who supported artists in different ways beyond the commercial relationships between buyer and seller were also heterogeneous with regard to ethnicity, social standing, profession and the reasons for philanthropic actions. Here one can detect the emerging traits of private patronage and similar forms of promoting art. (Ābele 2014: 103)

The rhetorical demand for ethnically particular Latvian art, articulated by artists themselves and public intellectuals, exceeded the real demand. While closer to the end of the period works of Latvian artists were both produced and bought more, the situation changed considerably only after the First World War, when Latvian state institutions for preserving and promoting art were established.

Career opportunities of nationally minded new artists were limited, to some extent, by the lack of exhibition prospects in their native country. The Riga City Art Gallery was established in 1868, and three years later it joined up with Kunstverein zu Riga (the Baltic German Riga Art Society), which was founded in the same year, 1872, with the aim of popularising visual arts and promoting art in the Baltic Provinces as well as holding exhibitions and compiling a collection of outstanding artworks. The successful cooperation between the two leading agencies of artistic life in the capital city Riga led to the building and establishing of the City Art Museum in 1905. The new building was shared with the Kunstverein. The museum collection consisted mainly of works by Baltic German and Western European artists. The museum held about 60 exhibitions before 1918, only four of which were solo shows by ethnic Latvian artists. Requests for the use of the premises for joint exhibitions by Latvian artists were rejected, sometimes leading to open conflicts and complaints filed by the Latvian Art Promotion Society of Riga City Council (Šmite 2005: 332). The Latvian Art Promotion Society was founded in 1910 with the purpose of promoting and collecting ethnic Latvian art. One of its aims was also to establish its own library 
and museum (Cielava 1986: 79), partially as a response to the aforementioned problems of exhibiting Latvian works at the City Museum (cf. Lāce 2005: 336; Cielava 1986: 77; Jaunsudrabiņš 1910: 3), and partially as an alternative to the Baltischer Künstler-Verband (Baltic Artists Union), which was not really welcoming towards the majority of Latvian artists (Kencis \& Kuutma 2011: 506). Between the first exhibition of works by ethnic Latvian painters (see below) in 1896, and shared exhibitions of Latvian artists regularly organised by the Latvian Art Promotion Society after 1910, artworks by Latvian artists were displayed both on the prominent premises of Baltic German dominated public art institutions ${ }^{4}$ and multiple other premises such as private salons, bookshops, and artists' studios open to the public, as well as sites of local art education (for a detailed overview see Ābele 2014). The increase in artistic activity was paralleled by the growing printing industry, which greatly contributed to public discourse on art. Latvian, German, and Russian-language periodicals regularly featured exhibition reviews as well as theoretical articles on art. The first years of the twentieth century saw the establishment of extended art sections in magazines like Vērotājs, Austrums, and Zalktis, with high-quality design and reproductions from local as well as foreign artists. Some of the leading Latvian artists, like Janis Rozentāls and Jūlijs Madernieks, also became the main contributors to art criticism.

Regarding style, the fin de siècle decades are called the period of Neoromanticism in Latvian art. In this period realism met strong influences of the Russian Peredvizhniki (Wanderers) artistic group, along with symbolism, postimpressionism, the 'modern style' or Art Nouveau, better known in this region by its German title Jugendstil; some late traits of national romanticism were also still present. As Jeremy Howard notes:

The distinction between styles was far from categorical or exclusive. Many artists experimented with different styles as they searched for their creative identities and markets. Sometimes the search overtly expressed the coincidence with political or national movements. At others it was more personal, subjective, or cosmopolitan. (Howard 1998: 128)

While discussions on inventing a particular 'national style' are covered below, at this moment the variety of genres listed above allows one to speak about a multi-directional cultural translation through the adaption of local content to international form. The process of translation, guided by personal agendas as well as market forces, occurred simultaneously on horizontal and vertical axes. The former represents stylistic adaptations and innovations of a formal nature, applying techniques learned abroad and from foreign sources (books, magazines, visits to exhibitions) to depict real or imagined local realities. The 
latter exemplifies the transfer of images from folklore and ethnography, allocated to the lower rung in the status hierarchy of cultural forms, to the framework of fine arts, which occupy the highest level of the same hierarchy. The fragmentary and multidirectional nature of this process was augmented by lack of history or existing tradition of national art, while at the same time marking a situation unique to the genesis of new cultures in the Baltic provinces as opposite to artistic processes in countries like France, the United Kingdom or Bohemia, where the agency of the fine art tradition was native. The relationship between Latvian national art and its counterparts in other countries was also a constant topic in local critical discourse, with appeals both to modernise the art and not to lose local particularity (Pelše 2007). During the formative process, several coexisting directions of creating national art can be distinguished. Visual art was 'nationalised' either via form - by interpreting ethnographic patterns of ornamentation - or via content. The latter ranges from depictions of local landscapes (Vilhelms Purvītis) and people (early Janis Rozentāls) to motifs of ancient history (Arturs Baumanis), folklore (Ādams Alksnis, Rihards Zariņš) and mythology (late Janis Rozentāls). The developing ethnic visual arts scene became a place of negotiation and exchange between international artistic techniques on the one hand and the construction of national cultural heritage on the other.

\section{FORMAL AND INFORMAL EDUCATION}

The formation of national art outside the 'national territory' was determined by institutional dispositions: there was no art academy or other higher level art education institution in the Baltic provinces. Consequently, the majority of Latvian artists around the turn of the century were trained in St. Petersburg - either at the Imperial Academy of Arts or at Stieglitz's School of Technical Drawing (with an official name: Stieglitz St. Petersburg State Academy of Art and Industry). At the end of the day, "this simultaneous education in the main art centre of Russia became a decisive factor not only in the individual masters' biographies but in the whole creation and development of the national art" (Ābele 2014: 51). It might be that interest in Latvian folklore, shared by artists analysed below, initially developed in this very environment. Here also the first organisation of Latvian nationally-oriented artists (musicians and other students of cultural subjects accompanying the majority of practitioners of fine art) was established. The illegal (due to strict laws on freedom of association) society named $R \bar{u} k, i s$ (The Gnome) was set up and its first meetings took place around the late 1880s, gradually involving almost every successful Latvian artist of the generation. 
Unfortunately, the archives of $R \bar{u} \not h i s$ and multiple other evidences were lost during the turmoil of the twentieth century, leaving future art historians with almost a single source - memories of sculptor Gustavs Škilters (1874-1954). "One of R $\bar{u} \not h i s$ 's main principles was that 'the artist must be a true son of his nation and age'." (Ivanovs 1958: 22) Or, as Škilters wrote: "Highly national spirit and folkish enthusiasm prevailed in R $\bar{u} k, i s . "$ Artists "pursued paths to the heart of the nation each in their own way; researched the folkish ways of expression, and tried to maintain and depict the national spirit, particularity, and tone in their works" (Škilters 1924: 217). The initiative to establish this society came from a less known folklore collector, teacher and publicist Kārlis Alberts Pētersons (1855-1917) (Ābele 2014: 56). The first leader of the artists' society was painter Ādams Alksnis (1864-1897). In the initial years he was one of the oldest representatives in the circles of St. Petersburg Latvian art students; it is rather believable that "due to his education and noble personal characteristics, Alksnis became an authority among Latvian art students and their ideological leader. [---] As a man and an artist, Alksnis notably influenced the new generation of artists. According to testimonies of contemporaries, the rigour of his character, model, encouragements and reprimands have, directly or indirectly, left an indelible imprint on those comrades who were closer to him" (Skulme \& Lapiňš 1954: 55).

As demonstrated in the analysis below, folklore characters and motifs were among the favourite subject matters of Alksnis's oeuvre. If not a direct influence, the artist's example might have been an encouragement to his compatriots to choose a similar direction in creative endeavours, both for regular artwork reviews at $R \bar{u} k, i s$ and during their later career. However, this course was not taken by Alksnis's successor Johann Walter (1869-1932).

Members of $R \bar{u} k, i s$ also constituted the majority of artists whose works were displayed at the first solely ethnic Latvian artists' exhibition in Riga. Such an opportunity occurred in the ethnographic realm, bypassing the space of 'pure' fine art, which was locally dominated by the Baltic German elite. The artworks were put on display during the 10th Pan-Russian Archaeological Congress in Riga in 1896, within an exhibition of Latvian ethnography (Vīksna \& Stradiñ 1997: 107; Ābele 2014: 59). The Latvian Ethnographic Exhibition was opened to the public from August 1st to September 15th, 1896, and was a huge success attended by more than 45,000 visitors. The anonymous author of the exhibition catalogue notes: "Previously artists paid little attention to the life of Latvians; by contrast, the new generation of artists mainly take the subject of their paintings from the life and nature of the Baltic countries" (Howard 1998: 131). However, the participation of nationally minded artists in this event, which at first glance was unrelated to the sphere of arts, was not an exception. As Latvia was just 
a province of the Russian Empire, the national representation at a Pan-Russian event might have been correlated with participation at World Fairs by other, independent countries: the national character was to be found best among the representations of other nations (cf. Hirsh 2003 on the Swiss case). The show at the Ethnographic Exhibition remained the greatest achievement in the joint efforts of the members of $R \bar{u} k, i s$. Later on the group gradually dissolved until its demise in about 1902, as its core members left the capital one by one after finishing their studies. Artists' education in St. Petersburg was usually continued by shorter or longer creative trips to Western Europe, especially Paris, and German creative centres like Berlin and Munich, giving them an opportunity to seize the most recent developments in artistic techniques and aesthetics of new popular styles. After graduation from educational institutions in the imperial capital, many members of $R \bar{u} k$, is moved to their native countryside with the purpose of picturing local landscapes and people. In a regional context, this process is similar to the well-documented Finnish artists' trips to the country's northern periphery - Karelia - constructing the image of the 'nation's cradle' located at a distance from the developed southern regions (cf. Häyrynen 2004; Lonkila 2010), or the German heimatkunst (homeland art) movement. In conclusion, one should agree that "as the group's members went their individual ways, their future relationship with Latvianness, Latvia, and the idea of national art differed widely. Nevertheless, they had created Latvian art as a growing phenomenon and for some of them, working in or for their homeland became an everyday reality" (Ābele 2014: 61). The careers of individual artists demonstrate preferences for particular forms of art, depending on the initial choice of the educational institution, but individual styles seem to be more influenced by later training abroad and other factors. Most likely the shared cultural space unofficially 'institutionalised' by $R \bar{u} \not, i s$ generated interest in national subjects and themes of artworks in spite of art market trends. Still, there was no 'control group' of Latvian artists at the end of the nineteenth century against the backdrop of which this hypothesis could be verified.

\section{SHARED LANDSCAPES AND DIVIDED IDENTITIES}

As the case of outstanding, internationally recognised landscape painter Vilhelms Purvitis (1872-1945) illustrates, the homeland and its everyday reality turned out to constitute complex sets of identities, where political, ethnic, personal, and financial trajectories often intersected in unexpected and inconvenient ways. On the one hand, local scenery and characters provide material for particularly national art only in a somewhat weak sense, i.e. due to refer- 
ences that inform the audience of the artwork. On the other hand, embedded in broader multichannel discourses, native landscapes became the locus of national identity in the late nineteenth century Europe (cf. Facos 2003: 236). Writing on English art history, Stephan Daniels generalises:

National identities are coordinated, often largely defined, by 'legends and landscapes', by stories of golden ages, enduring traditions, heroic deeds and dramatic destinies located in ancient or promised home-lands with hallowed sites and scenery. The symbolic activation of time and space, often drawing on the religious sentiment, gives shape to the 'imagined community' of the nation. As exemplars of moral order and aesthetic harmony, particular landscapes achieve the status of national icons. (Daniels 1993: 5)

The acquisition of this status is sustained by the dual interrelationship of portrayal (verbal or visual) and narration. To become part of national iconography, the same landscape appears in history writings and plays, tourist guides, and epic poetry; it is the subject of paintings and illustrations, and it appears in designs for postage stamps and banknotes. While this can be called the typical way of forging a national symbol, Purvititis succeeded in creating a rather 'essentially Latvian' type of landscape painting, characterised more by form than content.

Usually he painted birch groves or pine stands, snow drifts and ice floes in early spring, blooming trees of May or the colourful foliages of autumn. [---] The variations in the color palette, the softened contours and the technique of the brushwork render Purvitis's landscapes freely painterly, yet the compositional structure is strictly maintained. (Latvian Cultural Canon)

Immediately after graduating from the Academy of Arts in St. Petersburg with a Grand Gold Medal, Purvitis successfully participated in several major international exhibitions, acquiring international recognition and subsequent financial independence. Purvītis's solo shows were organised in Berlin, Dresden, Vienna, London and other art centres across Europe. However, away from the local context, the artist was perceived as, and called, a 'Russian painter' (see Âbele 2014: 89-90), adding one more dimension to his identity. Locally, at the beginning of the twentieth century, Purvitis was equally popular among the new ethnic Latvian middle class and representatives of the historic Baltic German elite, whose members proudly called him "unser landsmann", that is, our compatriot (Ābele 2006: 49). Even more so, in 1905 he wrote with some bitterness about the early years of his career: "German art writers have written about my then still only slightly popular painting in the most promoting way. 
German newspapers, in opposite to Latvian, have never printed any articles against my art." ${ }^{\prime 5}$ (Ābele 2012: 101) Declaring that the interests of art are more important than politics, the artist even spent some time living in Revel (contemporary Tallinn, Estonia) around the time of the 1905 revolts, due to unwillingness to take part in the events that had divided Latvian society into two radically opposite parts. Multiple publications on local art around the turn of the century (analysed in Ābele 2006, 2012; Pelše 2007) allow for a reconstruction of the hybrid domain of artistic practices, in which the same artists and their works can be denominated as Latvian and also as Baltic, with reference to the Baltic German notion of territorial identification. Public recognition and subsequent financial benefits proved Purvītis's success. Despite the dominance of the genre at exhibitions, no other artists succeeded in turning their landscapes into national symbols. Scenic paintings by Rozentāls and Walter remain in the background of their oeuvre while the nonconformist postimpressionist painter Voldemārs Zeltin̄š (1879-1909) deliberately avoided entering the art market. The weak link between the type of landscape and the desired expression of 'national spirit', recalled in Škilters's memories of Rūkis, demanded that artworks develop an alternative, more nationally particular content. And the discourse of folklore and ethnography provided such content, undisputedly Latvian, for the general public.

\section{WHY FOLKLORE}

The devil is one of the most popular characters in Latvian folktales and legends. In some tales he is a cunning, exquisite gentleman, dressed all in black and betrayed only by the goat footprints he leaves behind; in some others he is a monster with multiple heads. Many tales feature him as a hairy and naïve antagonist of God, always ending up as a fool. The latter image of the folk devil is represented along with other characters of folklore in the works by Âdams Alksnis, the first leader of $R \bar{u} k, i s$. The national character of Alksnis's oeuvre, contrary to Purvitis's landscapes, was not hidden in a specific use of stylistic devices or an original palette of colours. It was the content, the narrative of artworks that in 1904 allowed another great artist and art critique, Janis Rozentāls, to call him "the pioneer of true Latvian art" (R. 1904: 501). Alksnis, a student from the battaglia ${ }^{6}$ master class under the guidance of Bogdan Willewalde (1819-1903) at the Imperial Academy of Arts in St. Petersburg, devoted multiple works to compositions from the Baltic (including Latvian) history and historical warfare; typical examples in this regard are Senlatviešu kauja ar bruniniekiem (The Battle of Ancient Latvians and Knights, around 1890) 
and Izlüki (Scouts, mid-1890s). While Alksnis was also among the first artists to depict rural scenes and local types, his heritage of around 800 drawings, watercolours, and paintings includes works on other folklore motifs in addition to the devils mentioned above. For example, his picture Jātnieks pils priekš $\bar{a}$ (Rider in Front of the Castle, around mid-1890s) would, according to Rozentāls, be a good "fit for the illustration of a common phrase in our fairy-tales: 'and by darkness approaching, he suddenly saw in front of him a beautiful castle" (ibid.). It was by the same time that Latvian folklorist Ansis Lehris-Puškaitis had already published the first volumes of one of the basic collections of Latvian folklore, Latvian Folktales (1891-1903), consisting of almost 7000 fairy-tales and legends in total.

The relatively intense exploitation of folkloristic motifs in the works of Latvian artists was not coincidental. It was related to the special role of folklore in the articulation of national identity and culture. Commenting on the ideological currents born in Europe from Johann Gottfried Herder's famous celebration of folk culture, Joep Leerssen says:

What is more, it alerted all nations that were as yet without established 'high literature', that their cultural output, even if it took the (hitherto despised) form of oral folksong, was nonetheless a thing to be proud of, a manifestation of the nation's presence in the cultural landscape. (Leersen 2006: 100; cf. Bula 2008)

Already since the formation of nationalistic views in the mid-nineteenth century, there had been an increasing public demand for national culture that would express particularly ethnic Latvian imagery. Collections of folklore were among the first manifestations of national culture, inseparable from the cultural political agenda of liberating the nation. The end of the nineteenth century saw simultaneous publications of the largest collections of folksongs and folktales. Thus folklore was approved and celebrated as a national particularity at a time when an ethnically conscious generation of Latvian artists entered the stage of history. Consequently, one way in which the demand for national fine arts resulted was the borrowing of themes and images from folklore and mythology. However, Latvian national artists were awaited not only by the existing discourse on folklore, but also by foreign models of its adaptation into techniques and modes of visual arts. In this regard one of the geographically and politically closest trendsetters was Finland, extensively analysed by Pertti J. Anttonen (2005) and Derek Fewster (2006). This was not only through the influence of Finnish artist Akseli Gallen-Kallela, described in detail below, but also through the general image of Finnish cultural heritage. The latter served 
as a point of reference in the illustrious call for national mythology-inspired arts by art critic Jānis Liepiṇš as late as 1916:

But does our life lack substance, great events? And if not life, then Latvian mythology has stocked up great treasures of the Latvian soul over long centuries, providing rich matter and national themes for painting and poetry. Still, do we have a single character as the Finns have Väinämöinen and others? But Latvians have "wonderfully lovely antiquity" with the Latvian Bearslayer, the Devil, and the Thunder God with six sons who glance through the roses, and daughters of the moon. And in the northern sea, in a cold castle, the North Father rules with his daughter, and the tender-hearted God, walking upon the earth, doing good to everyone. [---] That is the world that locks the Latvian soul into symbols, a particular and infinitely beautiful world, and when diving into such a story, an individual artist can gain worldwide recognition. But foreigners ask about our art: Where does its particularity lie? (Liepiňš 1916: 1)

Despite Liepiṇš's journalese request, art history demonstrates that before 1916 folklore and mythology motifs were rather well represented in Latvian arts. For example, Alksnis was followed by his successor at the head of the Rūkis society, graphic artist Rihards Zarin,š (1869-1939), although already on a different scale and with much more proficiency. A graduate of Stieglitz's School of Technical Drawing in 1895, Zariņš continued his education in Berlin with graphic artist and illustrator Alexander Zick (1845-1907), in Munich with Rudolf von Seitz (1842-1910) and Maximillian Dasio (1865-1954), and in Vienna with William Unger (1837-1932), as well as studied lithography in Paris. Zariṇš later lived in St. Petersburg until 1919, which allows, with some certainty, to trace in his works the influence of the stylistic devices developed within the Russian modern group, Mir iskusstva (World of Art). For example, particular similarities appear in Zariņš's illustrations of fairy-tales and the works of Ivan Bilibin (1876-1942), illustrator, ethnographer, stage designer, and the author of the monograph Folk Arts of the Russian North (1904). Despite living abroad, Zariņ̌s actively participated in Latvian art life, illustrating books and periodicals, gathering ethnographic material and participating in exhibitions. During the last decade of the nineteenth century he explored a historically-decorative style close to German romantic tradition, also creating a well-known first example of pure Latvian national romanticism, the title page for a Latvian folksong edition, Latvju dainas, in 1894. Developing a synthesising approach to the modern style, Zariņš "made frequent redress to literary analogy and narrative" (Howard 1998: 137). A reviewer of his first exhibition in Riga in December 1899 emphasised: 
As a narrator of fairy tales and an illustrator, he combines a vigorous imagination with an outstanding decorative talent and graphic ability. The mysteries of the forest, goblins and elves, enchanted princesses guarded by ghastly dragons - all this and the like is presented in a pleasant, attractive manner. (ibid.)

Zariṇš authored allegorical representations of folklore, like Tautasdziesma (Folksong, 1892) and Pasaka (Fairy-tale, 1898), and depicted ancient Latvian gods like Pērkons (Thunder God, 1904), although his favourite subject still seems to have been scenes from folktales. He also created a series of works dedicated to one story, and was keen on making purely decorative drawings of all kinds of mythological beings from fairy-tales, such as gnomes, devils, mermaids, and dragons.

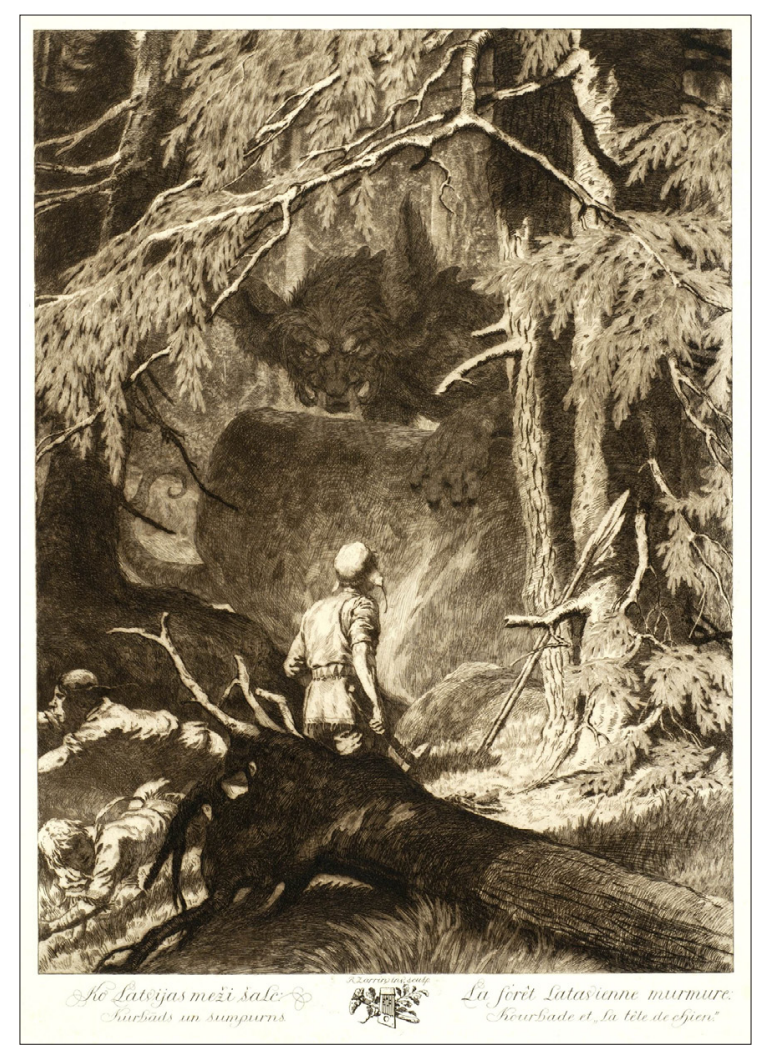

Figure 1. Rihards Zariņš. Kurbads un sumpurnis (Kurbad and Cynocephalus, 1908-1911). Latvian National Museum of Art. 
The history of various European countries demonstrates an extremely varied interest in folklore and the development of folkloristics as a discipline (cf. Ó Giolláin 2000). As such it might be correlated with the development of the discipline of history and the discovery of historical sources. The same also applies to visual arts: where traditions of historical painting bloomed, folklore gained much less prominence. An overview of the cultural developments of the (early) nineteenth century indicates: "In the field of painting and sculpture, themes from national history had become dominant, celebrating the glories and glorifying the tragedies from the nation's annals" (Leerssen 2006: 188). However, this tendency seems to have reached Latvia only in the last decade of the century. Several historical scenes, especially those related to ancient warfare, were created by Âdams Alksnis, although the paintings of Arturs Baumanis (1867-1904) gained more prominence in this regard. Baumanis, who was a student of the Imperial Academy of Arts, borrowed many stylistic devices from the most prominent German masters of academic historical painting, such as Wilhelm von Kaulbach (1805-1874), Alfred Rethel (1816-1859), and Karl von Piloty (1826-1886) (Latvijas mākslas vēsture). Baumanis's most famous painting Likten,a zirgs (The Horse of Destiny, 1887) (Fig. 2) is close to the manner of the Dusseldorf school, and like another large-scale historical composition, Kurši sadedzina savus mirušos (Couronians Burn Their Dead; end of the 1880s), illustrates a scene from the medieval Heinrici Chronicon Lyvoniae, recently translated into Latvian. Apart from these, Baumanis was commissioned by the Riga Latvian Society - the central cultural-cum-political institution of nationforming - to create a series of portraits of outstanding personalities from the national movement. His oeuvre also includes drawings on ancient Latvian history and illustrations to the epic poem Niedrīšu Vidvuds by Jēkabs Lautenbahs (1848-1928). For some time the latter was the main contestant for the honour of being the national epic, like the Finnish Kalevala or Estonian Kalevipoeg. Overall, Baumanis and Alksnis stand out in the construction of national art at the end of the nineteenth century as two authors developing the genre of historical painting. At the same time, they were the only members of the $R \bar{u}, k i s$ society who left the Academy of Arts before the Peredvizhniki reform of 1894; therefore their interest in historical scenes coincides with the curricula of prereform academia. Unfortunately, the premature deaths of both painters left these waters still for about two decades, while their contemporaries chose different styles and subjects for their creative endeavours. The lack of exemplary historical events worth national appraisal and celebration left a discursive gap in the construction of national identity, the latter being notably constituted by shared memories as a form of history. In Latvia, this gap, to some extent, was filled by an already accumulated symbolic capital of folklore. One can say that 


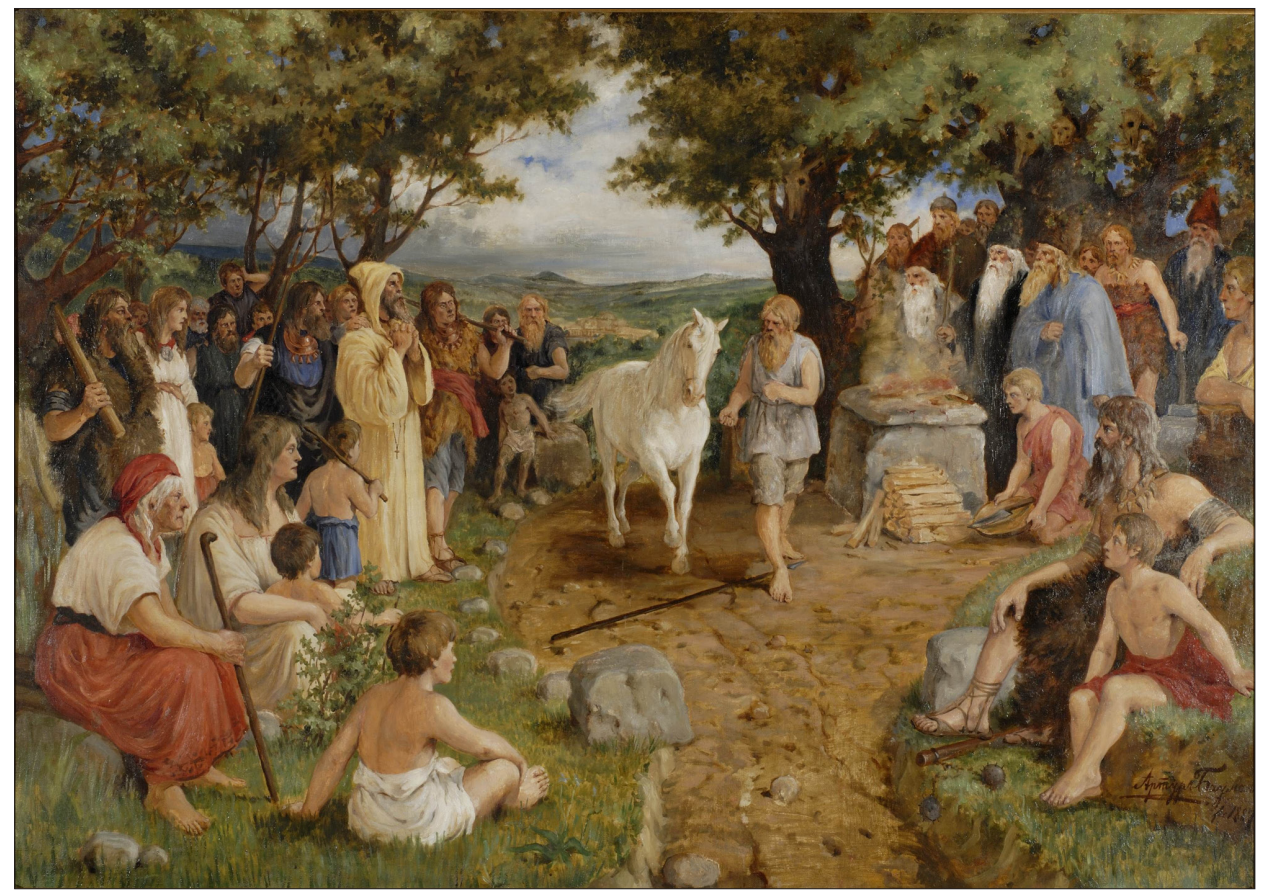

Figure 2. Arturs Baumanis. Liktena zirgs (The Horse of Destiny, 1887). Latvian National Museum of Art.

folklore filled the niche between two opposites (when talking of its value for nation-building) on the axis of national content in art: the anonymous landscape of the native land and the heroic events of the past.

\section{STYLE AND ORNAMENT}

In this regard, folklore went hand in hand with interest in ethnic tangible culture or, more precisely, folk ornament. While folklore materials are narrative and, as such, restricted to the narrative genres of art such as painting, drawing, and sculpture, folk ornament provides a wider choice of expressive forms within the realm of applied design. It might be awarded less prestige in the common hierarchy of arts, but at the same time it reaches a considerably wider market than constituted by elitist purveyors of painting and visitors to art exhibitions. The local blooming of the production of applied design items 
was related to a rapid increase in demand in the Baltic provinces, the most advanced region of the empire. Particular developments can be associated with two somewhat contradictory tendencies: the growing popularity of the modern style and the international Arts and Crafts Movement, established by artist and writer William Morris (1834-1896). According to Morris, design had to return to the organic simplicity of craftsmanship, adapting it to the spirit of time. Nationalisation of design was related more to decorations and patterns than the shapes of objects and materials; it drew inspiration and motifs from the ethnographic ornament, richly preserved in the fabrics of traditional folk costumes. In this regard a rather fierce public discussion occurred between two members of the Rūkis society - Jūlijs Madernieks (1870-1955) and Rihards Zariņš. Madernieks felt rather free regarding the stylisation of ethnographic ornaments and motifs, while Zariņš insisted on deeper studies of visual heritage and fewer changes during its adaptation to contemporary means.

According to Jeremy Howard, after the turn of the century Madernieks became Latvia's leading universalist, practicing graphic arts, embroidery, furniture and interior design as well as painting, teaching, and art criticism (Howard 1998: 134). Madernieks studied decorative painting at Stieglitz's school and later completed his study of professional standards in Paris, Munich, and London, thereafter settling in Riga in 1902. Akin to Swedish painter Gustaf Fjaested (1868-1948), whose works Madernieks is known to have studied, his landscapes echo modern style characteristics; his interiors designed from the first years of the twentieth century are also similar (ibid.). While in his early works Madernieks freely combined ornamental styles like those of traditionally Byzantine or Oriental and natural forms, his preferences later shifted more towards geometric patterns resembling Latvian folk ornament. Analysing Madernieks's writings on art theory, Latvian art historian Stella Pelše deduces that "Madernieks's ideas expose both elements of the aestheticist position of art's autonomy and references to art as the expression of the nation's collective spirit that can be traced back to Herder" (Pelše 2007: 42). Indeed, Madernieks himself wrote:

We only start to recognise a nation's cultural face if its art manifests the wonderful essence, which, like language, allows us to distinguish one nation from another. The more organically healthy and stronger the nation, and the more intense the impulses of national specificity, the more original an artist's work will be. (Madernieks 1914 (287): 2)

Despite using similar metaphors, Herder's influence here is doubtfully direct (cf. Baar 2010: 112). However, it cannot be dismissed as purely coincidental. Folksong collections of Herder's first Baltic correspondents established practices that were later directly continued by the emerging Latvian nationalists. At the 
end of the day, "the symbolic link between nation and oral poetry posited by Herder has had an enormous intellectual and political influence in the history of Latvian national identity, with its central symbolic image of the "nation of singers"' (Bula 2008: 7). This particularity of the nation-building served as a basis for the use of oral poetry, i.e. folklore, motifs in artworks of Latvian artists who contributed to the ongoing nation-building process at the same time. Naturally, Madernieks implemented his ideas of national art in his studio, where at some point he was teaching up to fifty students. Remembering the time before World War I, the artist recalls: "I tried to arouse interest in my pupils regarding our ancient spiritual world - folktales, folksongs, etc. I even assigned particular themes for sketches of compositions" (Madernieks 1940: 7). However, his own loose and sometimes only suggestive use of Latvian ornament provoked a fierce response from Zariňš, expressed in a series of articles in the press as well as in a letter to Rozentāls. The latter, cited also by Howard (1998), is worth quoting here in length to illustrate the nature of discussions about national heritage in contemporary art:

I have decided to go to war in the newspapers against Madernieks. Because it's nonsense to suppose you can modernise your national dress. Then it's not national dress any more. And when have you heard of any nation who has done it? You can modernise "Reform" clothes as much as you like - that's happened in Finland, Sweden and Norway. But no one has changed national costumes. Yet Madernieks does not feel that it is against the style. Just as he does not sense that you cannot mix Latvian woollen shawl ornaments with Russian book decoration - which is what he has done, on the Tālavietis invitation cards. [---] I am sure that Madernieks will be rude to me, even though my criticism is given with the best intentions... He will say that I am a shameless overseer, a Genghis Khan who suppresses freedom. But he does not realise how lacking in taste his work is. He needs about six overseers. (Howard 1998: 136)

Public discussions between Zariņš and Madernieks in several magazines and newspapers lasted for about a year, but final agreement was never reached and both approaches to cultural heritage, represented by these artists, continued to coexist well after World War I (cf. Ābele 2014: 98). Differences in approach to the stylisation of ornaments are quite distinctive in magazine contributions by both artists: designs in Zalktis (1907-1910) and Vērotājs (Wehrotajs, 1903-1905) by Madernieks and in Druva (1912) by Zariņš (all available at www.periodika.lv). Otherwise, the opinions of both artists are more comparable than their works due to difference between Madernieks's specialisation in interior and textile design and Zarinššs commitment to delicate visuals such as the designs of bank 
notes, stamps, and securities. Zariņš, in his decorative (as opposed to narrative, analysed above) works tried to remain faithful to ethnographic designs and to represent them more clearly, without distortion or mixing them with foreign traditions. Zariňš's revivalist stance also bears a resemblance to some of the core ideas of Herder, who wrote on the relationship of symbolic representational systems (like language and culture) and the regional specifics of nature and climate (e.g. Herder 2002: 150). In the same way Zariňš called for the creation of art that "has grown on the fundaments of ancient people's art and is adequate to the climate of the land and living conditions of the people" (Zariňš 1904: 148). Interestingly enough, his own works are not limited to the reproduction of old forms, instead representing distinct characteristics of modern style. Despite the obvious, Zariņš declared:

We will be aware not to spread that international plague of arts that fancies to call itself modern style, but in reality is not anything else than a style without a theory, a composition of pieces from English, German, and French art magazines. (ibid.)

In his later years, authoring a fundamental three-volume edition of Latvian ethnographic folk ornament (1924-1931), Zariņš could be compared with one of the establishers of the Estonian National Museum, Estonian artist Kristjan Raud (1865-1943). Both artists, representing the second generation of their respective nations, emphasised and practised research and collection of visual heritage, leaving its contemporary developments for later times (cf. Seljamaa 2006).

\section{SYMBOLISM AND DIVERSITY}

The most versatile relationship between the imagery of folklore and visual forms of fine arts is to be found in the legacy of Janis Rozentāls (1866-1916). Here we can see not only transmission of images from one discursive realm to another, but also a translation into the international language of fine arts, the latter emphasising parallels of folklore collection on the one hand and its creative visualisation on the other. Rozentāls was a distinguished artist and intellectual of his time, practising painting, graphic design, applied arts, teaching, and art criticism, to a large extent leading the local discourse on art theory in Latvia in the first decade of the nineteenth-century (cf. Rūķe-Draviṇa \& Tārs 1989; Howard 1998; Pelše 2007). He studied painting at the Imperial Academy of Arts in St. Petersburg from 1888 to 1894, at a time when the academy was being reformed and artists representing the realistically (as opposed to the classical 
academic tradition) oriented Peredvizhniki movement took teaching positions, the latter including Rozentāls's tutor Vladimir Makovsky (1846-1920). The reform created an opportunity for the students to freely choose the subjects of their compositions, which were no longer restricted by the framework of the classical programme. It could be the everyday reality or images from the realms of fantasy or folklore (Ābele 2014: 53). However, after the first nationalrealistic compositions with some traits of impressionism, Rozentāls explored a more conceptualist vocabulary in his oeuvre, merging national romanticism, symbolism, and post-impressionism. During his studies Rozentāls was an active member of the $R \bar{u} k, i s$ society and one of the main organisers of the Latvian art display at the aforementioned ethnographic exhibition. In a way, his paintings and drawings of fauns, satyrs, and devils, for example Pēc pirmajiem gailiem (After the First Cock-Crow, ca. 1905), can be regarded as a contribution to a friend and the $R \bar{u}$ ķis leader, Ādams Alksnis. However, compared to Alksnis or Zariňš, "Rozentāls's approach was more subjective, relying on a heightened individual interpretation of the surrounding reality and a lessened reliance on the conventions of stylisation" (Howard 1998: 139). Rozentāls was a renowned portraitist, while his figural compositions often refer, directly or allegorically, to Latvian folklore. Rozentāls's oeuvre is a prime example of the interplay of international formal qualities with both real and symbolic local content. However, some folklore motifs are so international that they cannot be attributed to a particular national tradition. Such as personified death in the eponymous painting Nâve (Death, 1897), merging the social realism of the late Peredvizhniki with the symbolists' mythical image in the haunted clarity of midday light, a time when, in Latvian folklore, the supernatural manifests itself as frequently as at midnight. Of similar uncertainty, regarding the original source, is another folklore-related painting, Gulbju jaunavas (Swan Maidens, ca. 1906). The same subject of merged human and animal features was also dealt with by famous Russian symbolist Mikhail Vrubel (1856-1910) in his 1900 masterpiece, Swan Princess. The subject of the painting is an internationally widespread folktale, listed in the Aarne-Thompson tale-type index under number 400. Of even more complex origin is Rozentāls's painting Teika (The Saga, 1899) (Fig. 3), featuring a naked female harpist against the background of the sea. Jeremy Howard indicates that the image might be related to Latvian deities of the sea, wind, or destiny (Howard 1998: 142). However, the only certain affinity that the image bears is a resemblance to La Muse (1898) by Henri Martin, the immensely popular painting shown at the Salon des Artistes Français the same year that Rozentāls visited Paris.

A more direct and certain reference to Latvian folklore is provided in two paintings by Rozentāls: the post-impressionist Saules meitas (Daughters of 


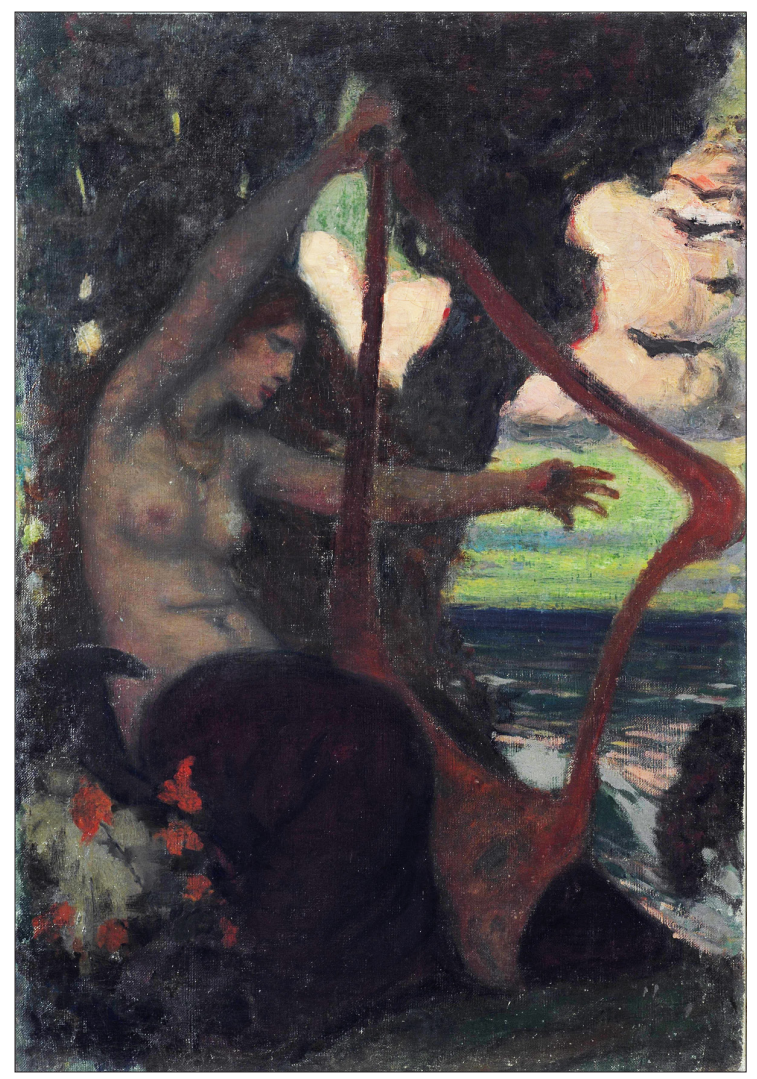

Figure 3. Janis Rozentāls. Teika (The Saga, 1899). Latvian National Museum of Art.

the Sun, 1912), depicting well-known Latvian mythical beings in an idyllic, sunlit environment, and Melna čūska miltus mala (The Black Snake Ground Flour, 1903) (Fig. 4). The latter is stylistically close to the works of the then famous Swiss symbolist Arnold Böcklin (1827-1901), the author of paintings that capture attention with dark, mythical, and sea-related imagery. Moreover, Rozentāls also authored an article on Böcklin in the monthly magazine Vērotājs (R. 1903). The title of Rozentāls's work is a reference to a Latvian folksong: "The black snake ground flour / in the middle of the sea, on a stone / that will be served to masters / who forced to work with no sun" (Krišjāṇa Barona Dainu skapis, No. 31348). The idea of the painting might be related to the suspense before the revolts of 1905 (see, e.g., Cielava 1974: 41). Interestingly, the same particular folksong motif was reproduced by another Latvian artist Rūdolfs 
Pērle (1875-1917) around 1916. Living in St. Petersburg after graduating from Stieglitz's school, Pērle established a distinctive style of his own, in later years developing imagery close to that of Lithuanian artist Mikalojus Konstantinas Čiurlionis (1875-1911), whose already famous works he might have seen in several exhibitions in St. Petersburg (Lamberga 2014: 60). Pērle worked in various media, for example watercolour, oil, etching, and others, depicting various subjects from purely decorative floral compositions to complex symbolic narratives. The Black Snake is not the only one of Pērle's works that refers to folksongs: Kara karodzina rakstittajja (Embroiderer of the War Flag, 1916) both illustrates a recognisable folklore motif and bears ethnographic ornament within the composition; the choice of words in the Latvian title of Saulìt vèlu vakarā (The Sun Late in the Evening, 1916) indicates a folksong; the same applies to the mythological motifs of Saules dèli karā jāja (The Sons of the Sun Rode into Battle, 1917). It seems that the artist's interest in particularly national (and, in two out of four, militant) subjects might have been related to the recent outbreak of World War I, which ravaged his native land of Latvia.

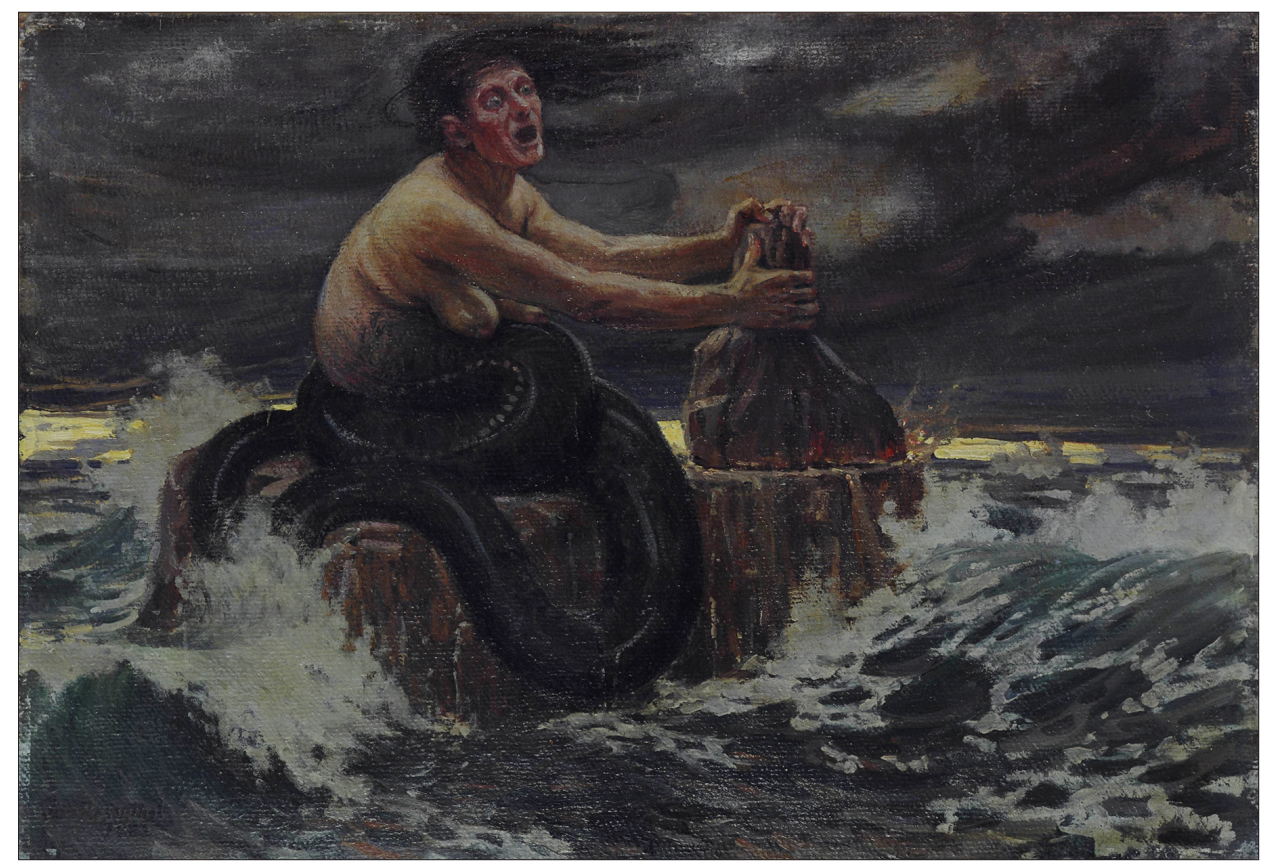

Figure 4. Janis Rozentāls. Melna čuska miltus mala (The Black Snake Ground Flour, 1903). Latvian National Museum of Art. 
The first lines of the folksong Kas tie tādi, kas dziedāja (Who Were Those Who Sung, 1913), and the names of the works of Rozentāls and Pērle, Melna čūska miltus mala (The Black Snake Ground Flour, ca. 1910) are also titles of artworks by another member of the Rūķis, Gustavs Škilters, Pērle's schoolmate at Stiglitz's School of Technical Drawing and later a student of French sculptor Auguste Rodin (1840-1917). Šķilters shares the titles Lietuvēns (Nightmare, 1910) and Gulbja meita (Swan's Daughter, i.e. the motif of the Swan Princess, 1911) with Rozentāls.

Returning to Rozentāls, two of his works are definitive in aligning international connections, stylistic innovations, and personal agenda in creating essentially national art. One such is the painting Vel̦ laiva (The Boat of Dead Souls, ${ }^{7}$ ca. 1905). The painting in many ways resembles The River of Death (1903) by Finnish painter Axeli Gallen-Kallela (1865-1931), who was "indeed the central figure in the resurrection of the so-called 'Kalevala art' in the 1890s" (Fewster 2006: 224). The importance of the folklore-based national epic Kalevala in Finnish nationalistic imagery is inestimable, and the symbolic charge that Kalevala-related art bears can surely inspire recreation of the same effect in other national traditions. Rozentāls visited Finland for the first time in 1896, sponsored by the Riga Latvian Society (Rūḳe-Dravina \& Tārs 1989: 27). He had probably also seen Gallen-Kallela's mural The Advent of Christendom or Christendom and Heathendom in the Finnish pavilion at the Paris Universal Exhibition in 1900. "Even in itself the Finnish pavilion was a statement of the political strength of Finnish nationalism, and displaying a praise of pagan culture bears testimony to the status Gallen already had as a "national painter" (Fewster 2006: 226). The artist definitely visited all three exhibitions of Finnish art held in Riga in 1901 and 1902, even though Rozentāls's relationship with Finnish culture became personal in 1903 when he married a Finnish opera singer, mezzo-soprano Elli Forsell (1871-1943). A few months before the marriage, Rozentāls wrote to his future father-in-law:

All your culture, particularly the art, is a sort of model for me. And being a painter, I most admire your great masters Gallen, Järnefelt, Hallonen, Saarinen and others, and my deepest longing is to become something of their kind here in Latvia. (Translated in Howard 1998: 144)

In subsequent years the artist often visited Finland, becoming personally acquainted with his idols and other Finnish intellectuals. Some researchers even claim that Pekka Halonen (1865-1933), renowned painter of Finnish national heritage, learned German with the purpose of conversing with Rozentāls (RūkeDraviṇa \& Tārs 1989: 31). 
The Finnish model is quintessential for the most monumental and, in a way, the most national of Rozentāls's works - a mural of seven friezes, made of coloured cement and mosaic, on the façade of the new building of the Riga Latvian Society (1910). The society, established in 1868, was at the time the centre of the Latvian national movement. The building, designed by Latvian architects Ernests Pole (1872-1914) and Eižens Laube (1880-1967), still occupies a prominent position on a boulevard at the very centre of the city. Referring to Latvian pagan mythology, these paintings "were in many respects Rozentāls's response to Gallen's Kalevala frescoes for the Finnish Pavilion in Paris ten years earlier" (Howard 1998: 144). Rozentāls's aim was to layer together four levels of symbolic meanings: pagan gods, who together represented the independent, ancient Golden Age of Latvians. Each god separately represents universal stages of the human lifecycle and human virtues: the Thunder God Pērkons represents maturity and power, Potrimps - youth and beauty, and Pīkols - old age and wisdom. Similarly, they represent the basic tripartite Indo-European cosmology: heaven, earth, and the underworld, respectively related to weather, fertility, and death. The fourth layer of symbolism refers to the activities of the Riga Latvian Society - art, science, industry, and agriculture. The deities painted by Rozentāls belonged to the national romanticist pantheon, as described in the poetry of Auseklis (Mikelis Krogzemis) (1850-1879) and in the national epic Lācplēsis (Bearslayer, 1888) by Andrejs Pumpurs (1841-1902). However, in the decades after the completion of Rozentāls's monumental work, the scholarly researchers of Latvian mythology unanimously agree that Pīkols and Potrimps were not genuine Latvian deities, but uncritical romanticists' borrowings from Prussian and Lithuanian sources (e.g. Šmits 1926).

Overall, Rozentāls skilfully balanced the local cultural capital of folklore and international recognition of mythical subjects of Symbolist art, ethnic national sentiments and close comradeship within the Baltic German society, creative work and creation of critical discourse, national uniqueness and following the best foreign examples. His artworks clearly illustrate the fact that national art shares the ambivalent nature of nationalism, which claims to be unique in any country, related to one particular land, language, nationality, and other properties; at the same time, the structure and mechanisms through which nationalism functions are very similar from country to country. In the meantime, comparative studies of art like this reveal broader field-specific dynamics: the interplay between the discursive realms of different statuses, ideals and markets, personal agendas and fashions for international styles, the layered fusion of international and national motifs. The Latvian case of the nationalisation of art around 1900 demonstrates specific recourse to folklore as an established and celebrated symbolic resource of national identity. 


\section{ACKNOWLEDGEMENTS}

Research for this article was supported by European Social Fund project, Cultures within a Culture: Politics and Poetics of Border Narratives.

\section{NOTES}

1 According to approximate data from the census of 1897, the Latvian-speaking population was $68.3 \%$, the Russian-speaking $-8 \%$, and the German-speaking $-7.1 \%$. The remaining largest minorities were Jews, Belarusians, and Poles, all together constituting 13.9\% (Bērziñ š 2000: 108). Almost $70 \%$ of the working population was employed in trade and farming (ibid.: 109).

2 The German Latvian Literary Society with the Latvian title, the Latvian Friends' Society (with all the colonial connotations this title bears), established in 1824 .

3 The German Provinces of Russia were industrially the most developed region in the Russian Empire, therefore urban areas were populated by rapidly increasing numbers of ethnic Latvian proletarians, the main audience for the whole range of politically left organisations from centric socialists to radical Bolsheviks.

4 Including the opening exhibition of the Riga Art Society Salon, where in 1898 an honourable place was occupied by the works of Vilhelms Purvitis, the most famous Latvian (and Baltic) artist.

5 Quoted from Ābele 2012, originally published in a currently unavailable supplement of Düna-Zeitung from 1905, No. 179: 1.

6 War-related paintings.

7 In the Latvian title “...of dead souls" uses the distinctively folkloristic term velu. In Soviet historiography the painting is also known as The River of Death.

\section{REFERENCES}

Ābele, Kristiāna 2006. Tautieši un novadnieki. Nacionālais jautājums un teritoriālā identitāte Latvijas mākslas dzīvē 19. gadsimta beigās un 20. gs. sākumā. [Fellow Nationals and Compatriots: The National Question and Territorial Identity in the Art Life of Latvia in the Late 19th and Early 20th Centuries.] In: D. Lāce (ed.) Mākssla un politiskie konteksti. [Art and Political Contexts.] Rīga: Neputns, pp. 39-63.

Ābele, Kristiāna 2012. Autoru meklējumos: Mākslas kritik̦i Baltijas un Pēterburgas vācu presē 19.-20. gs. mijā un viṇu dalība latviešu mākslas popularizēšanā. [Attribution of Authorship: Art Critics in the Baltic and St. Petersburg German Periodical Press around 1900 and Their Contribution to the Promotion of Latvian 
Art.] In: K. Ābele (ed.) Personība mākslas procesos. [Personality in the Processes of Art.] Rīga: Neputns, pp. 98-124.

Ābele, Kristiāna 2014. Artistic Life. In: E. Kḷaviṇš (ed.) Art History of Latvia IV: Period of Neo-Romanticist Modernism 1890-1915. Riga: Institute of Art History of the Latvian Academy of Art, pp. 31-173.

Anderson, Benedict 2006 [1983]. Imagined Communities. London \& New York: Verso. Anttonen, Pertti J. 2005. Tradition through Modernity: Postmodernism and the NationState in Folklore Scholarship. Helsinki: Finnish Literature Society.

Baar, Monika 2010. Historians and Nationalism: East-Central Europe in the Nineteenth Century. New York: Oxford University Press.

Bērzin̄š, Valdis (ed.) 2000. 20. gadsimta Latvijas vēsture: Latvija no gadsimta sākuma lìdz neatkarības pasludināšanai 1900-1918. [Latvian History in the 20th Century: Latvia from the Beginning of the Century to Independence 1900-1918.] Rīga: Latvijas vēstures institūta apgāds.

Bula, Dace 2008. Latvian Folksongs: Collected, Published and Studied. In: D. Bula \& S. Rieuwerts (eds.) Singing the Nations: Herder's Legacy. Trier: Wissenschaftlicher Verlag Trier, pp. 7-29.

Cielava, Skaidrīte 1974. Latviešu glezniecība buržuāziski demokrātisko revolūciju posmā (1900-1917). [Latvian Painting in Period of Bourgeois-Democratic Revolutions (1900-1917).] Rīga: Zinātne.

Cielava, Skaidrīte 1986. Latviešu tēlotāja māksla: 1860-1940. [Latvian Fine Arts: 1860-1940.] Rīga: Zinātne.

Daniels, Stephen 1993. Fields of Vision: Landscape Imagery and National Identity in England and the United States. Princeton: Princeton University Press.

Facos, Michelle 2003. Educating a Nation of Patriots: Mural Paintings in Turn of the Century Swedish Schools. In: M. Facos \& S.L. Hirsh (eds.) Art, Culture, and National Identity in Fin-de-Siècle Europe. Cambridge: Cambridge University Press, pp. 229-249.

Fewster, Derek 2006. Visions of Past Glory: Nationalism and the Construction of Early Finnish History. Helsinki: Finnish Literature Society.

Häyrynen, Maunu 2004. A Periphery Lost: The Representation of Karelia in Finnish National Landscape Imagery. Fennia, Vol. 182, No. 1, pp. 23-32. Available at http://ojs.tsv.fi/index.php/fennia/issue/view/627, last accessed on July 22, 2015.

Herder, Johann Gottfried 2002. Philosophical Writings. Translated and edited by Michael N. Foster. Cambridge: Cambridge University Press.

Hirsh, Sharon L. 2003. Swiss Art and National Identity at the Turn of the Twentieth Century. In: M. Facos \& S.L. Hirsh (eds.) Art, Culture, and National Identity in Fin-de-Siècle Europe. Cambridge: Cambridge University Press, pp. 250-285.

Howard, Jeremy C. 1998. Latvian National Romanticism and Art Nouveau: Origins and Synthesis. In: E. Grosmane (ed.) Romantisms un neoromantisms Latvijas mākssāa. [Romanticism and Neoromanticism in Latvian Art.] Rīga: AGB, pp. 128-153.

Hroch, Miroslav 1985. Social Preconditions of National Revival in Europe. Cambridge and New York: Cambridge University Press.

Ivanovs, Miķelis 1958. Gustavs Š ̦̌ilters. Rīga: Latvijas Valsts izdevniecība.

Jaunsudrabiṇš, Jānis 1910. "Baltijas mākslinieku biedrība" un latviešu mākslinieki. [Baltic Artists Association and Latvian Artists.] Latvija, Vol. 10, p. 3. 
Kencis, Toms \& Kuutma, Kristin 2011. National Museums in Latvia. In: P. Aronsson \& G. Elgenius (eds.) Building National Museums in Europe 1750-2010. Conference Proceedings from EuNaMus, European National Museums: Identity Politics, the Users of the Past and the European Citizen, Bologna 28-30 April, 2011. Linköping: Linköping University Electronic Press, pp. 497-519. Available at http://www.diva-portal.org/smash/get/diva2:450373/FULLTEXT01.pdf, last accessed on July 22, 2015.

Kḷaviņš, Eduards 1996. Latviešu portreta glezniecība 1850-1916. [Latvian Portrait Painting 1850-1916.] Rīga: Zinātne.

Krišjān,a Barona Dainu skapis. [Cabinet of Folksongs of Krišjānis Barons.] Available at www.dainuskapis.lv, last accessed on November 5, 2015.

Lāce, Māra 2005. Museum Time: 1918-2005. In: M. Lāce (ed.) Valsts Mākslas muzejs. [State Art Museum.] Rīga: Jumava, pp. 335-343.

Lamberga, Dace 2014. Rūdolfs Pērle. Rīga: Neputns.

Latvian Cultural Canon. Available at http://kulturaskanons.lv/en/1/5/42/, last accessed on July 22, 2015.

Latvijas mākslas vēsture. [Latvian Art History.] Available at www.makslasvesture.lv, last accessed on July 22, 2015.

Leerssen, Joep 2006. National Thought in Europe: A Cultural History. Amsterdam: Amsterdam University Press.

Liepiņš, Jānis 1916. Latviešu mākslinieciskais talants. [Latvian Artistic Talent.] Līdums, Oct. 20, No. 241, p. 1. Available at http://periodika.lv/periodika2-viewer/view/ index-dev.html\#panel:pp| issue:/p_001_lids1916n241| article:DIVL13 | issueTy pe:P, last accessed on November 10, 2015.

Lonkila, Helena 2010. Renne Haverinen: From a Guide of the Karelianists to a Mythic Character and Friend. In: M. Vélez Cea \& A. Waenerberg (eds.) Kalevala granaína: Myth, Image, Idea. Ranua: Mäntykustannus, pp. 57-77.

Madernieks, Jūlijs 1914. Ceturtā latviešu mākslinieku izstāde. [The Fourth Exhibition of Latvian Artists]. Latvija, No. 287, pp. 1-2; No. 289, pp. 2-3; No. 295, pp. 2-3; No. 298, pp. 5; No. 301, pp. 2.

Madernieks, Jūlijs 1940. Niklāva Strunkes 25 gadu mākslas izstāde. [The 25th Anniversary Art Exhibition of Niklāvs Strunke.] Jaunākās Ziñas, March 9, No. 57, p. 7. Available at http://www.periodika.lv/periodika2/\#searchResults;si mpleQuery=Nikl\%C4\%81va\%20Strunkes\%2025\%20gadu\%20m\%C4\%81kslas\%20 izst\%C4\%81de, last accessed on July 22, 2015.

Ó Giolláin, Diarmuid 2000. Locating Irish Folklore: Tradition, Modernity, Identity. Cork: University of Cork Press.

Pelše, Stella 2007. History of Latvian Art Theory: Definitions of Art in the Context of the Prevailing Ideas of the Time (1900-1940). Riga: Institute of Art History, Latvian Academy of Art.

R. 1903 = Rozentāls, Janis. Arnolds Beklins. Wehrotajs, Dec. 1, No. 2, pp. 236-243. Available at http://www.periodika.lv/periodika2/\#searchResults;simpleQuery= Arnolds\%20Beklins, last accessed on July 22, 2015.

R. 1904 = Rozentāls, Janis. Adams Alksnis. Wehrotajs, Jan. 1, No. 3, pp. 368-374; Feb. 1, No. 4, pp. 500-505. Available at http://www.periodika.lv/periodika2/\#searchRes ults;simpleQuery=Adams\%20Alksnis, last accessed on July 22, 2015. 
Rūḳe-Draviṇa, Velta \& Tārs, Juris 1989. Blaumanis, Rozentāls un Somija. [Blaumanis, Rozentāls and Finland.] In: V. Rūḳe-Dravina (ed.) Zari. Stockholm: The Baltic Scientific Institute in Scandinavia, pp. 25-73.

Seljamaa, Elo-Hanna 2006. Building Up/On Power: Representations of the Estonian National Character in the Works and Words of Kristjan Raud. Estonian Art, No. 2. Available at http://www.estinst.ee/Ea/heritage/seljamaa.html, last accessed on July 24, 2015.

Šḳilters, Gustavs 1924. Atmiṇas par Rūḳi. [Memories about Rūḳis.] Ilustrēts žurnāls, March 7, No. 10, pp. 216-217; March 14, No. 11, p. 241. Available at http:// www.periodika.lv/periodika2/\#searchResults;simpleQuery=Atmi\%C5\%86as\%20 par\%20R\%C5\%AB\%C4\%B7i, last accessed on July 24, 2015.

Skulme, Uga \& Lapiṇš, A. 1954. Janis Rozentāls. Rīga: Latvijas Valsts izdevniecība.

Šmite, Edvarda 2005. Art Comes into the Lives of the Citizens of Riga. In: M. Lāce (ed.) Valsts Mākslas muzejs. [State Art Museum.] Rīga: Jumava, pp. 328-334.

Šmits, Pēteris 1926. Latviešu mītoloǵija. [Latvian Mythology.] Rīga: Valters un Rapa.

Vīksne, Rudīte \& Stradiṇš, Jānis 1997. Rīgas Latviešu biedrības Zinību komisija Latvijas un Rīgas Kultūrvēsturē. [Scientific Committee of Riga Latvian Society in Cultural History of Latvia and Riga.] Latvijas vēstures institūta žurnāls, No. 3, pp. 103-126.

Zariņš, Rihards 1904. Mahksla un amats. [Art and Craft.] Austrums, No. 1, pp. 65-67, available at http://periodika.lv/periodika2-viewer/view/index-dev. html\#panel:pp| issue:/p_001_aust1904n01| article:DIVL346| issueType:P; No. 2, pp. 147-153, available at http://periodika.lv/periodika2-viewer/view/index-dev. html\#panel:pp | issue:/p_001_aust1904n02 | article:DIVL603 | issueType:P, both last accessed on November 11, 2015. 